\title{
Analisis Kesulitan Belajar Operasi Hitung Pada Siswa KelaS SATU SEKOLAH DASAR
}

\author{
Suwarto \\ STMIK Raharja Tangerang Jurusan Sistem Informasi \\ Jl. Jendral Sudirman No 40 Modernland, Tangerang, Indonesia \\ suwarto@raharja.info
}

\begin{abstract}
Abstrak
Penelitian ini bertujuan menganalisis kesulitan belajar operasi hitung pada siswa kelas satu Sekolah Dasar. Subyek penelitian ini adalah siswa kelas 1 SD Negeri Ketapang Kecamatan Mauk Kabupaten Tangerang, dengan metode diskriptif kualitatif. Teknik pengumpulan data menggunakan tes. Hasil analisis didapat: (1) Letak kesulitan siswa dalam memahami operasi bilangan adalah dalam hal fakta, hal ini ditunjukan ketika menyelesaikan soal bentuk cerita, dalam operasi penjumlahan soal cerita dalam katagori kurang baik yaitu sebesar $25 \%$ siswa dapat mengerjakan soal dengan benar. Pada soal cerita operasi pengurangan kemapuan penyelesaian siswa dalan katagori kurang baik yaitu sebesar $22,5 \%$ siswa yang dapat mengerjakan soal dengan benar. (2) Siswa masih mengalami kesulitan jika dimodelkan dalam bentuk abstrak, hal ini terlihat pada soal yang dimodelkan abstrak pada operasi pengurangan sebesar $50 \%$ siswa dapat menyelesaikan soal dengan baik dan pada operasi pengrungan terdapat $37,5 \%$.

Kata Kunci:kesulitan belajar, operasi hitung, penjumlahan dan pengurangan
\end{abstract}

\begin{abstract}
This study aims to study how to learn count on the first grade students of Primary School. The subjects of this study were the students of grade 1 of the State Elementary School of Ketapang, Mauk Sub-District, Tangerang Regency, with qualitative descriptive method. Technique of writing data using test. The results of the analysis obtained: (1) The location of the students' difficulties in understanding the operation of numbers is in fact facts, this is shown keterhubungan about the form of the story, in the process of summing up the story story in less good category that is equal to $25 \%$ of students can do the problem correctly. On the matter of operation story to trap the release of student dalan less good category that is equal to $22,5 \%$ student who can do the problem correctly. (2) Students are still difficult if modeled in abstract form, this is seen in the problem that is moderated. A total of $50 \%$ of students can solve the problem well and on the operation there are $37.5 \%$ pengrungan there.
\end{abstract}

Keywords: learning difficulties, counting operations, addition and evaluation 


\section{Pendahuluan}

Pendidikan adalah usaha secara sadar serta terencana guna menciptakan kondisi belajar dan proses pembelajaran yang dilakukan oleh peserta didik untuk aktif mengembangkan potensi yang dimiliki serta membekali peserta didik dengan kekuatan spiritual keagamaan, pengendalian diri, kepribadian, kecerdasan, akhlak mulia, dan keterampilan yang diperlukan bagi pribadinya, masyarakat, bangsa dan negara (Hanafy, 2014). Usaha pengembangan potensi diri dapat diwujudkan melalui interaksi yang bersifat edukasi antara peserta didik dengan pendidik sebagai pusat pelaku proses belajar. Pendidik sebagai fasilitator yang dapat menempatkan diri guna mengikuti dan mengarahkan peserta didik dalam usahanya mengembangkan potensi diri setiap peserta didik perlu melakukan interaksi yang baik sehingga potensi setiap peserta didik dapat tercapai.

Menurut Gagne (dalam Susanto,2016), belajar adalah suatu proses yang terstruktur dalam upaya merubah perilaku manusia yang disebabkan dari pengalamannya. Belajar dimaksudkan sebagai suatu proses guna mendapatkan motivasi dalam memperoleh pengetahuan, keterampilan, kebiasaan, dan tingkah laku. Dalam proses siswa atau peserta didik untuk mendapatkan pengetahuan atau keterampilan pada jenjang sekolah dasar perlu dilakukan melalui perintah. Perintah yang dimaksudkan adalah arahan dan bimbingan dari seorang pendidik atau guru, sehingga motivasi selalu terbangun dalam melakukan proses belajar ketika di ruang kelas.

Matematika merupakan bagian dari ilmu pengetahuan yang mengajarkan kepada siswa untuk berpikir secara rasional, kritis, analitis dan sistematis. Menurut (B.Uno, 2009), matematika digunakan sebagai suatu studi yang dimulai dari pengkajian bagian-bagian yang sangat dikenal menuju arah yang belum dikenal. Bagian yang dikenal merupakan pengalaman pribadi setiap individu siswa, kemudian secara bertahap dihadapkan pada kondisi yang rumit atau belum dikenal. Misalnya dimulai dari secara konkrit bahwa setiap siswa dapat menunjukan banyaknya kelereng selanjutnya secara abstrak akan mengenal simbol bilangan.

Menurut Widdiharto (dalam (Waskitoningtyas, 2016), kesulitan belajar adalah kurang berhasilnya siswa dalam menguasai konsep, prinsip, atau struktur penyelesaian masalah, walaupun telah berusaha untuk mempelajarinya. Kemampuan dalam mengabstraksikan suatu permasalahan dalam hal ini adalah konsep operasi bilangan, baik penjumlahan atau pengurangan berkemungkinan dipengaruhi oleh kebiasaan siswa dalam permasalahan-permasalahan konkrit. Letaknya adalah pada transisi bagaimana merubah dari hal kongkrit ke dalam hal abstrak.

Bilangan merupakan suatu konsep dalam proses pencacahan dan pengukuran (Suwarto, 2017). Pencacahan dapat 
dimisalkan ketika seseorang menunjukan banyaknya benda, dan pengukuran bisa ditunjukan ketika menunjukan panjang, tinggi, atau berat suatu benda.

Pada proses pembelajaran mata pelajaran matematika di kelas satu sekolah dasar sudah diperkenalkan operasi bilangan yaitu penjumlahan dan pengurangan (Djaelani, 2008). Mulanya siswa diperkenalkan konsep bilangan dengan secara konkrit menunjukan pencacahan atau menunjukan banyaknya benda baik berbentuk benda-benda konkrit atau yang divisualkan dalam bentuk gambar. Operasi bilangan yang merupakan dasar untuk menyelesaikan operasi operasi lain yang lebih rumit perlu dikuasai dengan baik, penelitian ini untuk mengetahui kesulitan siswa dalam belajar operasi hitung, dan kemudian setelah dapat dianalisa kesulitan-kesulitannya tentu dapat menjadikan masukan bagi para guru sekolah dasar khususnya kelas satu untuk menentukan metode pembelajaran yang tepat, kemudian kesulitan-kesulitan dalam pemahaman operasi hitung siswa dapat diatasi.

Kesulitan belajar adalah suatu bentuk ketidakmampuan siswa dalam menguasai konsep, prinsip, fakta, dan keterampilan (Sholihah \& Afriansyah, 2017). Gejala yang terlihat ketika siswa tidak lagi mampu mengusai sesuatu yang baru dalam hal ini penguasaan materi operasi hitung adalah siswa tidak mampu berkonsentrasi, mengalami kelelahan dan kejenuhan.

Tujuan dari penelitian ini adalah: (1) mendiskripsikan kesulitan belajar siswa kelas satu sekolah dasar pada materi operasi hitung (penjumlahan dan pengurangan), (2) mendiskripsikan faktorfaktor yang menyebabkan kesulitan belajar siswa kelas satu sekolah dasar pada materi operasi hitung (penjumlahan dan pengurangan).

\section{Metode}

Jenis penelitian ini adalah penelitian deskriptif dengan pendekatan kualitatif, dengan maksud bahwa pendekatan kualitatif adalah suatu proses penelitian dan pemahaman yang berdasarkan pada metodologi yang menyelidiki suatu fenomena sosial dan masalah manusia (Ekayanti, 2017). Penelitian kualitatif mempunyai tujuan menggambarkan dan mengungkap masalah atau fenomena, Pendekatan kualitatif bersifat deskriptif dimaksudkan penelitian ini bertujuan mendeskripsikan fenomena-fenomena yang terjadi baik fenomena yang bersifat alami atau rekayasa (Sukamadinata, 2011).

Penelitian ini dilakukan di SD Negeri Ketapang Kecamatan Mauk Kabupaten Tangerang, sebagai subyek penelitian adalah siswa kelas satu Sekolah Dasar Negeri Ketapang Kecamatan Mauk Kabupaten Tangerang beserta guru kelasnya.

Metode pengumpulan data yang dipakai dalam penelitian ini adalah observasi, wawancara, dan tes, dengan teknik ini diharapkan peneliti memperoleh informasi yang berkaitan dengan data penelitian yang diharapkan oleh peneliti. 
Dalam melakukan observasi peneliti melakukan pengamatan secara langsung serta pencatatan pada lembar observasi terhadap kegiatan yang dilakukan oleh guru dan siswa dalam proses belajar mengajar, guna mengetahui kesulitan belajar siswa dalam belajar matematika pada materi operasi bilangan. Kemudian peneliti juga melakukan wawancara terhadap siswa dan guru untuk mengetahui faktor-faktor penyebah terjadinya kesulitan yang dihadapi pada materi operasi bilangan.

Tes tertulis dipakai untuk mengukur kemampuan peserta didik dalam kemampuannya untuk memecahkan masalah operasi bilangan. Bentuk tes dalam penelitian ini adalah essay sebanyak 5 soal. Pada tes tertulis akan ditentukan presentase setiap soal dijawab dengan benar, dimana besar presentase merupakan perbandingan frekuensi banyaknya siswa yang menjawab dengan benar dengan banyaknya siswa kali seratus persen.

$$
\text { Persentase }(\%)=\frac{F}{N} \times 100 \%
$$

Keterangan:

$\mathrm{P}=$ Presentase

$F=$ Frekuensi banyaknya siswa yang menjawab benar

$\mathrm{N}=$ Banyaknya siswa

Teknik analisis data yang digunakan dalam penelitian kualitatif dilakukan dengan langkah-langkah antara lain: (1) Reduksi data, (2) Penyajian data, (3) Penarikan kesimpulan dan verifikasi. Untuk hasil tes peneliti mengkatagorikan hasil analisis data tes menggunakan skala likert
(Arikunto,2010), dimana peneliti mengkatagorikan menjadi lima katagori yaitu katagori sangat baik, baik, cukup baik, belum baik. lebih jelasnya terlihat dalam tabel berikut:

Tabel 1.

\begin{tabular}{ccc|}
\multicolumn{3}{c}{ Katagori kemampuan opersi Hitung siswa } \\
\hline No & Presentase & Katagori \\
\hline 1 & $81 \%-100 \%$ & Sangat baik \\
\hline 2 & $61 \%-80 \%$ & Baik \\
\hline 3 & $41 \%-60 \%$ & Cukup baik \\
\hline 4 & $21 \%-40 \%$ & Kurang baik \\
\hline 5 & $0 \%-20 \%$ & Belum baik
\end{tabular}

\section{Hasil dan PeMbahasan}

Hasil wawancara yang dilakukan terhadap beberapa siswa dan guru, mengenai kesulitan belajar operasi bilangan kesulitan belajar siswa adalah sebagai berikut: (1) Siswa kurang memahami simbol, hal ini dibuktian dari keterangan siswa yang belum bisa menjawab soal dengan benar. (2) Penggunaan proses berpikir yang keliru, keterangan ini didapat dari siswa yang belum dapat menjawab soal dengan benar. Kekeliruan yang terjadi adalah tertukarnya dalam menghitung operasi penjumlahan dan pengurangan. (3) Perhitungan yang salah. (4) Kesulitan dalam membaca soal, menurut keterangan guru, siswa yang belum mampu mengerjakan soal dengan benar masih belum lancar membaca.

Dalam pengamatan langsung ketika proses belajar mengajar berlansung, didapat hasil yang menjadi penyebab faktor-faktor yang menyebabkan kesulitan belajar siswa dalam operasi hitung, antara lain: (1) Minat belajar siswa. (2) Motivasi 
belajar siswa, hal ini terlihat dari kemauan siswa belajar jika ditunggu oleh orangtua. (3) Cara mengajar guru yang membosankan. (4) Fasilitas belajar, sekolah yang terletak didaerah pinggiran atau pisisir pantau utara Kabupaten Tangerang dan kurang mendapat perhatian dari Pemerintah daerah.

Dalam pembahasan mengenai hasil tes yang dilakukan sebanyak 40 siswa, diperoleh hasil sebagai berikut:

1. Dari soal nomor 1, bentuk soal disajikan dalam bentuk gambar yang menunjukan operasi penjumlahan, pada gambar 01 menunjukan jumlah batang lidi, siswa diminta memberi jawaban ada berapa batang lidi, jika jumlah lidi kotak pertama ditambah jumlah lidi kotak kedua sebagaimana terlihat seperti gambar 01 berikut:

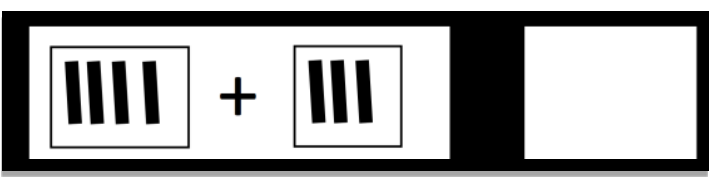

Gambar 1.

Terlihat dari bentuk soal tersebut yang menggambarkan operasi penjumlahan sebanyak 36 siswa menjawab dengan betul atau $90 \%$ siswa menjawab dengan betul. Ini menunjukan apabila dikatagorikan menggunakan skala likert bahwa sebanyak 36 dalam mengerjakan soal nomor satu dalam katagori sangat baik karea berada pada kisaran $81 \%$ - 100\%.

Menurut keterangan guru bahwa siswa tidak mengalami kesulitan jika menjawab pertanyaan terkait operasi penjumlahan bilangan yang dimodelkan melalui benda konkrit. Hal ini juga sesuai dengan kemampuan siswa ketika ditanya secara lisan atau langsung, siswa tidak mengalami kesulitan.

2. Soal nomor 2 merupakan operasi pengurangan, pada soal ini masih menggunakan soal dalam bentuk gambar menggunakan ambaran batang lidi, siswa diminta menunjukan banyaknya batang lidi jika batang lidi dari kotak pertama diambil, maka sisa lidi yang ada seberapa banyak.

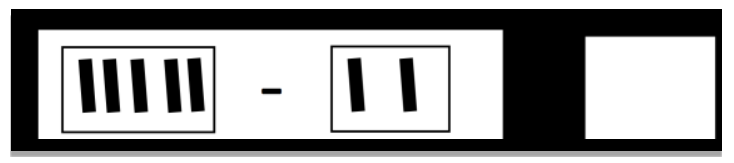

Gambar 2.

Dari soal nomor 2 terlihat bahwa sebanyak 33 siswa mampu mengerjakan dengan benar atau 82,5\% siswa mampu menjawab dengan benar. Hal ini menunjukan bahwa katagori siswa pada katagori sangat baik, hal ini dibuktikan bahwa $82,5 \%$ siswa yang menjawab dengan benar pada interval $81 \%$ - 100\%.

Menurut keterangan guru bahwa siswa tidak mengalami kesulitan jika menjawab pertanyaan terkait operasi pengurangan bilangan yang dimodelkan melalui benda konkrit. Hal ini juga sesuai dengan kemampuan siswa ketika ditanya secara lisan atau langsung, siswa tidak mengalami kesulitan. Walaupun dalam hal ini ada penurunan jumlah siswa yang menjawab dengan benar pada pertanyaan tersebut, ini dikarenakan kesiapan siswa dalam menjawab soal yang kurang. 
3. Pada soal nomor 3 siswa diminta menjumlahkan dua bilangan dengan bentuk lambang bilangan tidak lagi menggunakan bentuk gambar, soal terlihat seperti berikut ini:

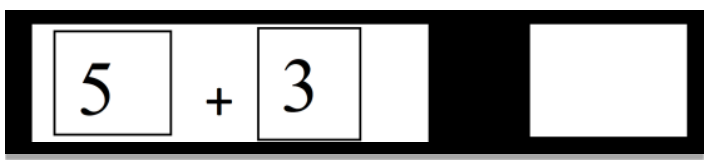

Gambar 3.

Soal nomor 3 memperoleh hasil bahwa sebanyak 20 siswa menjawab dengan benar, persentase banyaknya siswa menjawab dengan benar sebesar 50\%. Hal ini jika dikonversikan terhadap katagori kemampuan operasi hitung siswa berada pada katagori cukup baik sebab berada pada selang $41 \%$ sampai dengan $60 \%$. Pada soal bentuk ini siswa terlihat ada penurunan jumlah yang menjawab dengan benar, hal ini terjadi terdapat peralihan bentuk penyampaian operasi penjumlahan bilangan dari model konkrit ke bentuk abstrak, ternyata terdapat siswa yang masih mengalami kesulitan penyelesaian permasalahan operasi penjumlahan jika bentuk soalnya dimodelkan abstrak.

4. Pada soal nomor 4 siswa diminta menjawab hasil dari operasi pengurangan, seperti terlihat pada gambar berikut:

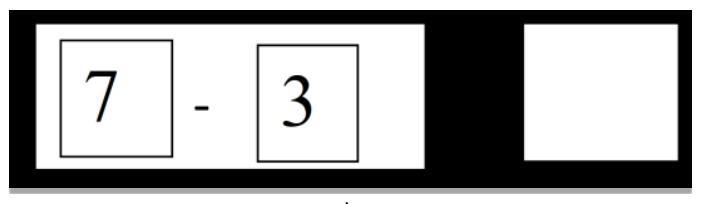

Gambar 4.

Soal nomor 4 diperoleh hasil sebanyak 15 siswa menjawab soal dengan benar, persentase banyaknya siswa menjawab dengan benar sebesar 37,5\%. Hal ini jika dikonversikan terhadap katagori kemampuan operasi hitung siswa berada pada katagori kurang baik sebab berada pada selang $21 \%$ sampai dengan $40 \%$.

Sama halnya pada soal nomor 3, persentase banyaknya siswa dalam menjawab dengan benar mengalami penurunan.

5. Soal nomor 5 siswa diminta menjawab soal cerita yang mengaplikasikan operasi penjumlahan, seperti terlihat berikut ini:

Aji memiliki 5 buah kelereng kemudian Aji dibelikan kelereng oleh ayahnya sebanyak 6 kelereng, keleremg Aji menjadi sebanyak .... kelereng

Gambar 5

Soal nomor 5 memperoleh hasil bahwa sebanyak 10 siswa menjawab dengan benar, persentase banyaknya siswa menjawab dengan benar sebesar 25\%. Hal ini jika dikonversikan terhadap katagori kemampuan operasi hitung siswa berada pada katagori kurang baik sebab berada pada selang $21 \%$ sampai dengan $40 \%$.

Pada soal bentuk cerita tampak bahwa siswa kurang memahami, hal ini kemampuan siswa dalam menyimak soal cerita masih kurang disebabkan kemampuan membaca masih belum lancar sehingga ketika disungguhkan soal bentuk cerita, guru perlu membantu membacakan soal. Jika soal hanya dibaca oleh siswa saja 
tanpa ada bantuan guru maka siswa masih kesulitan dalam menyelesaikannya

6. Soal nomor 6 siswa diminta menjawab soal cerita yang mengaplikasikan operasi pengurangan, seperti terlihat berikut ini:

Aji memiliki 7 buah kelereng kemudian Aji memberikan 2 kelereng kepada adiknya, keleremg. Kelereng Aji menjadi sebanyak .... kelereng

Gambar 6

Pada soal nomor 5, terdapat 9 siswa yang menjawab dengan benar, persentase banyaknya siswa menjawab dengan benar sebesar 22,5\%. Hal ini jika dikonversikan terhadap katagori kemampuan operasi hitung siswa berada pada katagori kurang baik sebab berada pada selang $21 \%$ sampai dengan 40\%. Sama halnya seperti soal nomor 5 siswa mengalami kesulitan jika bentuk soal cerita disampaikan.

Hasil tes siswa lebih lengkap disajikan dalam tabel berikut, hasil ini menunjukan banyaknya siswa menjawab soal dengan benar dan persentase banyaknya siswa dalam menjawab soal dengan benar.

Tabel 2.

Distribusi Presentase Jawaban Siswa

\begin{tabular}{ccc|}
\hline No. Soal & Frekuensi jawaban benar (F) & Persentase Jawaban Benar (\%) \\
\hline 1 & 36 & $90 \%$ \\
\hline 2 & 33 & $82,5 \%$ \\
\hline 3 & 20 & $50 \%$ \\
\hline 4 & 15 & $37,5 \%$ \\
\hline 5 & 10 & $25 \%$ \\
\hline 6 & 9 & $22,5 \%$ \\
\hline
\end{tabular}

Dari hasil analisa yang diperoleh, guru perlu memodelkan pembelajaran operasi bilangan agar konsep operasi bilangan dapat dipahami dengan baik, pemodelan yang dimaksud yaitu menyampaikan materi operasi bilangan dengan benda konkrit. Matematika diperkenalkan melalui tahapan konkrit, semikonkrit dan kemudian abstrak.

Masih banyak variabel lain yang mengakibatkan kemampuan pemecahan operasi hitung siswa mengalami kesulitan, sehingga mudah-mudahan ada penelitian lain yang mengalisa kesulitan - kesulitan memahmi operasi bilangan pada siswa kelas 1 SD.

\section{Penutup}

Bedasarkan hasil analisis yang telah dilakukan, maka dapat disimpulkan hal-hal sebagai berikut: 1) Kesulitan belajar siswa pada operasi hitung sebabkan hal-hal sebagai berikut: siswa kurang memahami simbol, proses berpikir yang keliru, dan perhitungan yang salah; 2) Faktor-faktor yang menyebabkan kesulitan belajar siswa pada operasi hitung adalah: minat belajar siswa kurang, motivasi belajar siswa kurang, cara mengajar guru yang 
membosankan, dan fasilitas belajar; 3) Dari hasil tes essay, dapat disimpulkan: a) Letak kesulitan siswa dalam memahami operasi bilangan adalah dalam hal fakta, hal ini ditunjukan ketika menyelesaikan soal bentuk cerita, dalam operasi penjumlahan soal cerita dalam katagori kurang baik yaitu sebesar 25\% siswa dapat mengerjakan soal dengan benar. Pada soal cerita operasi pengurangan kemapuan penyelesaian siswa dalan katagori kurang baik yaitu sebesar 22,5\% siswa yang dapat mengerjakan soal dengan benar; dan b) Siswa masih mengalami kesulitan jika dimodelkan dalam bentuk abstrak, hal ini terlihat pada soal yang dimodelkan abstrak pada operasi pengurangan sebesar 50\% siswa dapat menyelesaikan soal dengan baik dan pada operasi pengurungan terdapat 37,5\%.

Berdasarkan hasil penelitian tersebut maka disarankan: 1) Kepada guru kelas 1 SD Negeri Ketapang kabupaten Tangerang dan pada umumnya, agar konsep operasi bilangan dapat dipahami maka penyampaian terlebih dahulu melalui bentuk konkrit, kemudia semikonkrit dan abstrak; dan 2) Memastikan terlebih dahulu kemampuan membaca dan pemahaman factual (permasalahan aplikasi operasi bilangan)

\section{Daftar Pustaka}

Anderson, L. W., \& Krathwohl, D. R. (2010). Kerangka landasan untuk pembelajaran, pengajaran, dan asesmen: revisitaksonomi pendidikan bloom.

(TerjemahanAgung

Prihantoro). New York:

Ardiansyah, Gigih Sudarka. (2014). Kesulitan Belajar Matematika Siswa

Kelas VIII Sekolah Menengah Pertama Negeri 1 Sambi Tahun 2013/20014. Skripsi, tidak dipublikasi. Universitas Muhammadiyah Surakarta.

Arikunto, Suharsimi. (2010). Prosedur Penelitian Suatu Pendekatan Praktik. Jakarta: Rineka Cipta.

Aunurrahman. (2009). Belajar dan Pembelajaran. Bandung: Alfabeta.

B.Uno, H. (2009). Mengelola Kecerdasan dalam Pembelajaran. Jakarta: PT. Rineke Cipta.

Djaelani. (2008). Matematika untuk SD/MI Kelas I. Surakarta: PT Pustaka Utama.

Ekayanti, A. (2017). Diagnosis Kesalahan mahasiswa dalam Proses Pembuktian Berdasarkan Newman Error Analisis. Mosharafa: Jurnal Pendidikan Matematika, Vol 6 No 1 Hal. 105-116. Hanafy, M. S. (2014). Konsep Belajar dan Pembelajaran. Lentera Pendidikan, Vol. 17 Nomor 1 halaman 66-79.

Sholihah \& Afriansyah. (2017). Analisis Kesulitan Siswa dalam Proses Pemecahan Masalah Geometri Benda serta Tahapan berpikir Van Hiele. Mosharafa: Jurnal Pendidikan Matematika, Vol 6 No 2 Hal. 287-298. Sukamadinata, N. S. (2011). Metode Penelitian Pendidikan. Bandung: PT Remaja Rosa Karya.

Soon, W., Lioe, L, T., \& Mclnnes, B. (2011).Understanding the difficulties faced by engineering undergraduates 
in learning mathematical modelling. InternationalJournal of Mathematical Education inscience and Technology. 42, 1023- 1039.

Sukamadinata, N. S. (2011). Metode Penelitian Pendidikan. Bandung: PT Remaja Rosa Karya.

Susanto, A. (2016). Teori Belajar dan Pembelajaran di Sekolah Dasar. Jakarta: Kencana.

Suwarto. (2017). Strategi Pembelajaran

Operasi Bilangan dengan Bneda Konkrit. Union: Jurnal Pendidikan Matematika, Vol 5 No 3, Hal 285-294.

Waskitoningtyas, R. S. (2016). Analisis Kesulitan Belajar Matematika Siswa Kelas V Sekolah Dasar Kota Balikpapan Pada materi Satuan Waktu Tahun Ajaran 2015/2016. Jurnal IImiah
Pendidikan Matematika, Vol 5 No 1 Hal 24-32.

Widdiharto, Rachmadi. (2008). Diagnosis Kesulitan Belajar Matematika SMP dan Alternatif Proses Remidinya. Yogyakarta: Pusat Pengembangan dan PemberdayaanPendidik dan Tenaga Kependidikan Matematika

\section{Riwayat Hidup PenUlis}

Suwarto, M.Pd.

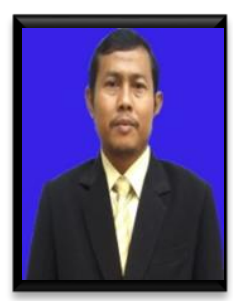

Lahir di Kebumen, 16 April 1978. Dosen Tetap Jurusan Sistem Informasi STMIK Raharja-Tangerang. 
This page is intentionally left blank 